\title{
Immunohistochemical and histoplanimetrical study on the endothelial receptor involved in transportation of minute chylomicrons into subepithelial portal blood in intestinal villi of the rat jejunum
}

\author{
Ei-ichirou TAKAHARA ${ }^{1)}$, Hideto YUASA ${ }^{1)}$, Miho NISHIDA ${ }^{1)}$, Youhei MANTANI ${ }^{1)}$, \\ Kankanam Gamage Sanath UDAYANGA ${ }^{2)}$, Wang-Mei QI ${ }^{3)}$, Takashi TAKEUCHI ${ }^{4}$, Toshifumi YOKOYAMA ${ }^{5)}$, \\ Nobuhiko HOSHI ${ }^{5)}$ and Hiroshi KITAGAWA ${ }^{1) *}$ \\ 1) Laboratory of Histophysiology, Department of Bioresource Science, Graduate School of Agricultural Science, Kobe University, 1-1 \\ Rokkodai-cho, Nada-ku, Kobe, Hyogo 657-8501, Japan \\ ${ }^{2)}$ Laboratory of Immunology, Institute of Basic Medical Sciences, Graduate School of Comprehensive Human Sciences, University of \\ Tsukuba, 1-1-1 Tennodai, Tsukuba, Ibaraki 305-8575, Japan \\ ${ }^{3)}$ Department of Basic Veterinary Medicine, College of Veterinary Medicine, Inner Mongolia Agricultural University, 306 Zhaowuda \\ Road, Huhhot, Inner Mongolia 010018, P. R. China \\ ${ }^{4)}$ Department of Veterinary Laboratory Animal Science, Faculty of Agriculture, Tottori University, 4-101 Koyama-cho Minami, Tottori \\ 680-8553, Japan \\ ${ }^{5)}$ Laboratory of Molecular Morphology, Department of Bioresource Science, Graduate School of Agricultural Science, Kobe University, \\ 1-1 Rokkodai-cho, Nada-ku, Kobe, Hyogo 657-8501, Japan
}

(Received 22 August 2014/Accepted 26 November 2014/Published online in J-STAGE 11 December 2014)

ABSTRACT. A portion of the minute chylomicrons less than $75 \mathrm{~nm}$ in diameter are transcytosed from the extravascular tissue into the subepithelial blood capillaries (sBC) in the villous apices of the rat jejunum. However, the details of the transportation mechanism have not been clarified. In this study, the endothelial receptor involved in the transportation of minute chylomicrons into the sBC's lumina was immunohistochemically and histoplanimetrically examined in intestinal villi of the rat jejunum. Immunopositivity for very low density lipoprotein (VLDL) receptor was detected on the luminal and basal surfaces of the endothelial cells of sBC in approximately $68 \%$ of those apices of jejunal villi that possessed numerous chylomicrons in the lamina propria, while VLDL receptor was detected on the endothelial cells of sBC in only approximately $8 \%$ of intestinal villi that possessed few or no chylomicrons in the lamina propria. No immunopositivity for $\mathrm{LDL}$ receptor was detected in the $\mathrm{sBC}$ of all intestinal villi. These findings suggest that VLDL receptor is expressed by the endothelial cells of the $\mathrm{SBC}$ in conjunction with the filling of the lamina propria of jejunal villi with many chylomicrons produced by the villous columnar epithelial cells and that the VLDL receptor mediates the transportation of minute chylomicrons, maybe VLDL, into the subepithelial portal blood from the extravascular tissue of the rat jejunal villi.

KEY WORDS: immunohistochemistry, minute chylomicron, rat, small intestine, VLDL receptor

doi: 10.1292/jvms.14-0432; J. Vet. Med. Sci. 77(4): 387-393, 2015

Chylomicrons in the broad sense are made from long and medium-fatty acids derived from foods in the villous columnar epithelial cells of the small intestine [11]. Until quite recently, chylomicrons discharged into the lamina propria from the villous columnar epithelial cells were thought to be transported only by the central lymph vessels (CLV) and never by blood capillaries in the intestinal villi $[10,11,23]$. However, a previous ultrastructural and histoplanimetrical study demonstrated that a portion of the minute chylomicrons less than $75 \mathrm{~nm}$ in diameter are transported by not only CLV but also subepithelial blood capillaries $(\mathrm{sBC})$ and that minute chylomicrons encapsulated

\footnotetext{
*Correspondence to: Kitagawa, H., Laboratory of Histophysiology, Department of Bioresource Science, Graduate School of Agricultural Science, Kobe University, 1-1 Rokkodai-cho, Nada-ku, Kobe, Hyogo 657-8501, Japan. e-mail: hkitagaw@kobe-u.ac.jp (C)2015 The Japanese Society of Veterinary Science

This is an open-access article distributed under the terms of the Creative Commons Attribution Non-Commercial No Derivatives (by-nc-nd) License $<$ http://creativecommons.org/licenses/by-nc-nd/3.0/>.
}

by cell membranes are transported into the lumina of the sBC through endothelial cells in the rat jejunum [41]. From these findings, the transportation of minute chylomicrons into the lumina of sBC is assumed to be performed by receptormediated transcytosis in the endothelial cells of sBC.

Soluble complexes of proteins and lipids in human and animal blood plasma, including all intestinal chylomicrons in the broad sense, are generally called plasma lipoproteins $[21,35,40]$. Plasma lipoproteins are clinically classified into chylomicrons in the narrow sense (more than $75 \mathrm{~nm}$ in diameter), intestinal very low density lipoproteins (VLDL: 75 to $28 \mathrm{~nm}$ in diameter), low density lipoproteins (LDL: 27 to $21 \mathrm{~nm}$ in diameter) and high density lipoproteins (HDL: 12 to $7 \mathrm{~nm}$ in diameter) based on their diameters and specific gravities during centrifugation [16, 21]. The chylomicrons in the broad sense include both chylomicrons in the narrow sense and VLDL [33, 34, 37].

All plasma lipoproteins are composed of 2 nm-thick shells and hydrophobic cores made up of both triacylglycerides and cholesterol ester. The shells consist of phospholipids, cholesterol and apolipoproteins, which are classified as apoA 
(A-I, A-II and A-IV), apoB (B48 and B100), apoC (C-I, C-II and $\mathrm{C}-\mathrm{III})$, apoD and apoE proteins $[16,21]$. The VLDL produced from the liver possess apoB100, apoC (I, II and III) and apoE, but not apoA-I, apoA-II, apoA-IV, apoB48 or apoD proteins $[16,45]$. In contrast, all intestinal chylomicrons in the broad sense, which include intestinal VLDL and LDL, possess apoA-I, apoA-II, apoA-IV, apoB48, apoC (I, II and III), apoD and apoE, but not apoB100 protein [16, 22, 44].

Plasma lipoproteins are generally recognized by VLDL receptor, LDL receptor or apoB48 receptor on the various cells in the organisms [13-15]. Plasma lipoproteins with apoE proteins, VLDL or LDL, are endocytosed by VLDL receptor or LDL receptor [15]. On the other hand, VLDL receptor proteins and their mRNA have been detected in the endothelial cells and the smooth muscles of umbilical veins by in situ hybridization and immunohistochemistry [29], and in the endothelial cells of blood capillaries or arterioles in the striated muscle tissue and the brain by immunohistochemistry [47]. The LDL receptor has also been detected in the endothelial cells of blood capillaries in the brain by dot blot assay [26]. However, apoB48 receptor which binds to apoB48 proteins has been reported to be expressed only by cultured macrophages and monocytes $[13,14]$. Therefore, the minute chylomicrons in the broad sense - i.e., less than $75 \mathrm{~nm}$ in diameter [41] — are assumed to be recognized and bound by VLDL receptor or LDL receptor on the endothelial cells of $\mathrm{sBC}$ in the rat small intestine. The aim of the present study was to demonstrate the contribution of VLDL receptor or LDL receptor to the transportation of minute chylomicrons into the lumina of $\mathrm{sBC}$ in the rat jejunum.

\section{MATERIALS AND METHODS}

Experimental animals: A total of 5 male Wistar rats aged 7 weeks (Japan SLC Inc., Hamamatsu, Japan) were used. The animals were maintained under conventional laboratory housing conditions and permitted free access to water and food (Lab MR Stock; Nosan Corp., Yokohama, Japan). The animal facility was maintained under conditions of a 12-hr light/dark cycle at $23 \pm 1{ }^{\circ} \mathrm{C}$ and $50-60 \%$ humidity. Clinical and pathological examinations were performed for all animals, and no signs of disorder were observed. This study was approved by the Institutional Animal Care and Use Committee (Permission number: 22-05-01) and carried out according to the Kobe University Animal Experimentation Regulations.

Tissue preparation: Rats were intravascularly perfused with $0.1 \mathrm{M}$ phosphate-buffered $4 \%$ paraformaldehyde fixative (4\% PFA; pH 7.4) after euthanasia with an intraperitoneal injection of $200 \mathrm{mg} / \mathrm{kg}$ of pentobarbital sodium (Kyoritsu Seiyaku Corp., Tokyo, Japan). After perfusion, small tissue blocks were obtained from a $5 \mathrm{~cm}$ segment that was $10 \mathrm{~cm}$ caudal from the duodenojejunal flexure and immersed in $4 \%$ PFA at $4{ }^{\circ} \mathrm{C}$ for $6 \mathrm{hr}(\mathrm{pH} \mathrm{7.4)}$. After fixation, the tissue blocks were finally immersed in a mixture of sucrose-O.C.T. compound (Sakura Finetek Japan, Tokyo, Japan) with reference to the embedding method described by Barthel and Raymond [1]. Then, all tissue blocks were snap-frozen in liquid nitrogen. Sections with $4 \mu \mathrm{m}$ thickness were cut using a Coldtome HM505E (Carl Zeiss, Jena, Germany) and were placed on slide glasses precoated with $0.2 \%$ 3-aminopropyltriethoxysilane (Shin-Etsu Chemical, Tokyo, Japan). The sections were stored at $-30^{\circ} \mathrm{C}$ until use.

Immunohistochemistry: The detection of antigens was conducted using the indirect method of enzyme immunohistochemistry. Briefly, after rinsing with $0.05 \%$ Tween-added $0.01 \mathrm{M}$ phosphate buffered saline (TPBS; $\mathrm{pH}$ 7.4), the sections were immersed in absolute methanol and $0.5 \% \mathrm{H}_{2} \mathrm{O}_{2}$ solution for $30 \mathrm{~min}$, respectively. TPBS rinse was performed three times after all preparation steps to remove any reagent residues. Following blocking with Blocking One Histo (Nacalai Tesque, Kyoto, Japan) for 1 $\mathrm{hr}$ at room temperature (r.t.), the sections were reacted with anti VLDL receptor goat IgG (diluted at 1:100; Santa Cruz Biotechnology, Dallas, TX, U.S.A.) or anti LDL receptor goat IgG (diluted at 1:200; Santa Cruz Biotechnology) for $18 \mathrm{hr}$ at $6^{\circ} \mathrm{C}$. The specificities for the primary antibodies are described in the manufacturer's specification forms (VLDL receptor, sc-10107; LDL receptor, sc-11824), respectively. Then, the sections were incubated with horseradish peroxidase-conjugated anti goat IgG chicken IgG (diluted at 1:200; Bethyl Laboratories, Montgomery, TX, U.S.A.) for $1 \mathrm{hr}$ at r.t. The specificity for the secondary antibody is described in the manufacturer's specification form (A200-116P-9). Finally, the sections were incubated with 3,3'-diaminobenzidine (Dojindo Lab., Mashiki, Japan) containing $0.03 \% \quad \mathrm{H}_{2} \mathrm{O}_{2}$ and were counterstained with methyl green. Control sections were incubated with TPBS or non-immunized goat IgG instead of the primary antibody.

Lipid staining: To clarify the relationship between the chylomicron production and the expression of VLDL receptor or LDL receptor in the intestinal tissue, sections from each tissue block for immunohistochemistry were also stained with Sudan Black B (Chroma, Münster, Germany).

Quantitative histology: Twenty intestinal villi with numerous chylomicrons in the lamina propria of villous apices and 20 villi with few or no chylomicrons in the lamina propria were randomly chosen from intestinal villi centrally sectioned along the villous axes in the jejunum of each animal. Then, the number of intestinal villi with VLDL receptor or LDL receptor-immunopositive $\mathrm{sBC}$ in their apices was counted, and their relative number was calculated in each animal. Finally, the average rates of the intestinal villi with the immunopositive $\mathrm{sBC}$ were calculated from 5 animals.

Statistical analysis: Data are presented as the means \pm standard deviations. Student's $t$-test was employed in the statistical analysis. $P$ values less than 0.05 were considered statistically significant.

\section{RESULTS}

General findings of chylomicrons in the intestinal villi: The villous columnar epithelial cells which possessed numerous fat droplets in their cytoplasms were restricted at 

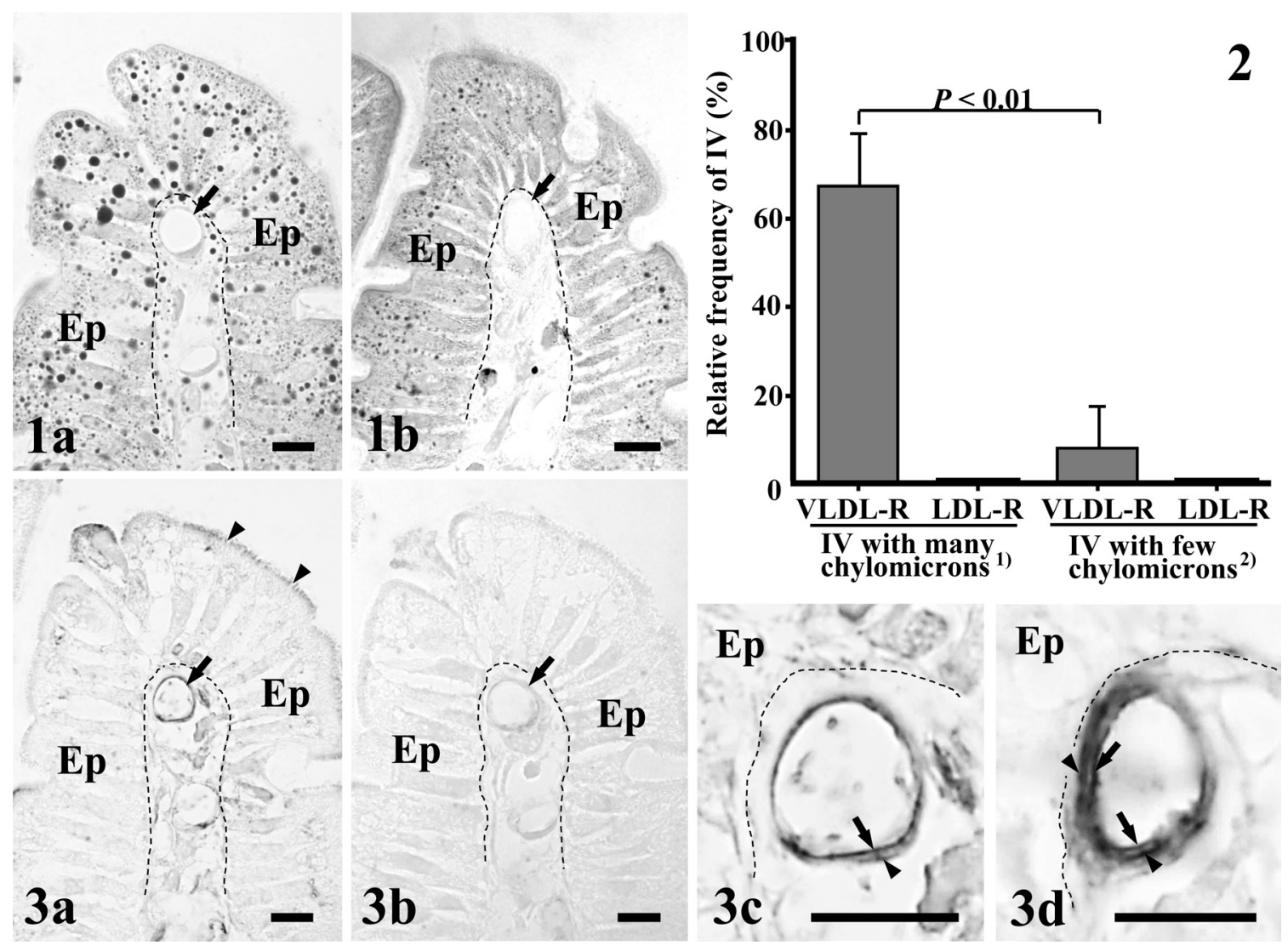

Fig. 1. Villous apices with Sudan Black B staining. a) Numerous lipid droplets and chylomicrons are visible in the epithelium and the lamina propria, respectively. b) A few lipid droplets are visible in the epithelium, but there are very few chylomicrons in the lamina propria. In all micrographs, the dashed lines indicate the border between the epithelium and the lamina propria. Arrow, subepithelial blood capillary. Ep, epithelium. Bar $=10 \mu \mathrm{m}$.

Fig. 2. Relative frequency of intestinal villi (IV) expressing VLDL receptor (VLDL-R) or LDL receptor (LDL-R) on the endothelial cells of the subepithelial blood capillaries. 1) Intestinal villi with numerous chylomicrons in the lamina propria. 2) Intestinal villi with few or no chylomicrons in the lamina propria. Each value represents the mean \pm SD.

Fig. 3. Serial sections of Fig. 1a. a) VLDL receptor-immunopositive blood capillary (arrow) is visible beneath the villous epithelium. The positive immunoreaction is also situated in the striated border of the epithelial cells (arrowheads). b) No immunopositive reaction for LDL receptor is visible in the villous apex. Arrow, subepithelial blood capillary. c) High magnification of the VLDL receptor-immunopositive subepithelial blood capillary in Fig. 3a. The luminal (arrow) and basal (arrowhead) cell membranes of an endothelial cell are immunopositive for VLDL receptor. d) High magnification of a VLDL receptor-immunopositive subepithelial blood capillary in a different villus with many chylomicrons. The luminal (arrows) and basal (arrowheads) cell membranes of an endothelial cell are immunopositive for VLDL receptor. In all micrographs, the dashed lines indicate the border between the epithelium and the lamina propria. Ep, epithelium. Bar=10 $\mu \mathrm{m}$.

the apices or from the apices to the middle portions of most intestinal villi. In these intestinal villi, many chylomicrons were distributed in the lamina propria beneath the epithelial cells with fat droplets (Fig. 1a). Few or no chylomicrons were present in the lamina propria of a few intestinal villi whose epithelial cells possessed the small amounts of fat droplets (Fig. 1b).

Immunohistochemical findings of $s B C$ : VLDL receptor was immunopositive in the endothelial cells of sBC of the villous apices in approximately $68 \%$ of intestinal villi whose lamina propria possessed numerous chylomicrons beneath the epithelial cells (Figs. 2 and 3a), but no LDL receptor was detected in the endothelial cells of any sBC (Figs. 2 and 3b).
The immunopositivity of the $\mathrm{sBC}$ for VLDL receptor was restricted in the most villous apices, but reached to the middle portions of a few intestinal villi. The immunopositivity for VLDL receptor was found at the cytoplasms and both the luminal and the basal surfaces of the endothelial cells of sBC. The immunopositivity of the cytoplasms was weaker than that of the cell membranes in the endothelial cells of sBC (Fig. 3c and 3d).

In the intestinal villi which had few or no chylomicrons in the lamina propria beneath the epithelial cells, the immunopositivity for VLDL receptor was detected in the endothelial cells of sBC in only $8 \%$ of intestinal villi (Figs. 2 and 4a). No LDL receptor was detected in the endothelial 


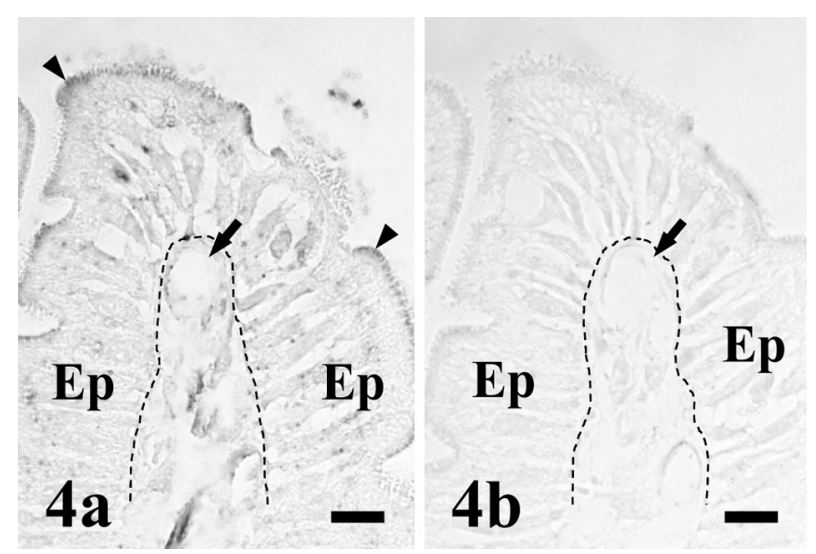

Fig. 4. Serial sections of Fig. 1b. a) No VLDL receptorimmunopositivity is visible in the endothelium of the subepithelial blood capillary (arrow) beneath the epithelium, but weak positive immunoreaction is visible in the striated border of epithelial cells (arrowheads). b) No immunopositive reaction for LDL receptor is visible in the villous apex. Arrow, subepithelial blood capillary. In all micrographs, the dashed lines indicate the border between the epithelium and the lamina propria. Ep, epithelium. Bar=10 $\mu \mathrm{m}$.

cells of sBC in all those intestinal villi that had few or no chylomicrons in the lamina propria-adjacent epithelial cells (Figs. 2 and 4b).

Other immunohistochemical findings: The striated borders of villous columnar epithelial cells were faintly immunopositive for VLDL receptor in a portion of the intestinal villi (Figs. 3a and 4a). The positive epithelial cells were mainly restricted to the villous apices. A few endothelial cells were immunopositive for VLDL receptor in arterioles or venules of the submucosa (Fig. 5a and 5b) and in blood capillaries of the muscular layer (Fig. 5c). The immunopositivity for VLDL receptor was detected strongly in the cell membranes and weakly in the cytoplasms of almost all the villous myocytes in the lamina propria (Fig. 5d) and the smooth muscle cells in both the lamina muscularis and muscular layer (Fig. 5e and 5f). The VLDL receptor was also weakly immunopositive in smooth muscle cells of a portion of the arterioles and venules in the submucosa (Fig. $5 \mathrm{a}$ and $5 \mathrm{~b}$ ). The endothelial cells of a few lymph vessels were immunopositive for VLDL receptor (Fig. 5g). The above immunopositivities for VLDL receptor were found regardless of the amount of chylomicrons in the lamina propria of intestinal villi. The other tissue elements were negative for VLDL receptor in all intestinal villi.

LDL receptor immunopositivity was observed in the endothelial cells of a few arterioles, venules and lymph vessels of the submucosa, in the blood capillaries of the muscular layer and in smooth muscle cells of venules of the submucosa (Fig. 6a-6d). The above immunopositivities for LDL receptor were found regardless of the amount of chylomicrons in the lamina propria of intestinal villi. The other tissue elements were negative for LDL receptor in all intestinal villi.

No immunopositive reactions were detected in any of the control sections.

\section{DISCUSSION}

The VLDL receptor has been immunohistochemically detected in the endothelial cells and smooth muscle cells of human arterioles and venules [29], in the villous columnar epithelial cells of the rat jejunum [12] and in human smooth muscle cells [31]. The tissue elements that exhibited VLDL receptor immunopositivity in the present study were consistent with those showing VLDL receptor immunopositivity in previous reports, indicating the high specificity of the antibody against VLDL receptor used in this study. The immunopositivity for VLDL receptor in smooth muscle cells might indicate that smooth muscle tissues require many free fatty acids as an energy source [36].

The LDL receptor has been detected in the endothelium of blood capillaries of the bovine brain by western blot analysis [26] and by immunoelectron-microscopical method [46]. This receptor has also been detected in cultured human vascular smooth muscle cells by western blot analysis [38]. In the present study, LDL receptor was detected in several vascular endothelium and the vascular smooth muscle cells. However, LDL receptor is never detected in other tissue elements, including the villous columnar epithelial cells, as shown in the mouse small intestine [30]. Thus, it was confirmed that the antibody used in this study had high specificity for LDL receptor. The LDL functions as the delivery agent for transporting cholesterol ester to peripheral tissues [21]. Therefore, the immunopositivity for LDL receptor in vascular endothelial cells and smooth muscles might also indicate that vascular tissues in the intestine require a lot of cholesterol ester.

The transcytosis of a portion of minute chylomicronsi.e., those less than $75 \mathrm{~nm}$ in diameter-by $\mathrm{sBC}$ from the extravascular tissue to the lumina of $\mathrm{sBC}$ has been demonstrated in rat jejunal villi and speculated to be mediated by some apolipoprotein receptors [41]. In tissues other than the liver, the VLDL receptor is thought to mediate the uptake of apoE-bearing lipoproteins [32, 42, 43]. In the present study, VLDL receptor was also expressed in the cell membranes of the endothelial cells of sBC, suggesting the possibility that apoE-bearing lipoproteins are transported from the extravascular tissue. In addition, the frequency of appearance of VLDL receptor-positive $\mathrm{sBC}$ was significantly higher in the intestinal villi with numerous chylomicrons than in the intestinal villi with few or no chylomicrons. No LDL receptor was detected in the sBC of any of the intestinal villi. Therefore, these findings suggest that VLDL receptor is expressed in $\mathrm{sBC}$ in conjunction with the filling of the lamina propria with many chylomicrons and mediates the transcytosis of minute chylomicrons including VLDL from the extravascular lamina propria into the lumina of $\mathrm{sBC}$ in rat jejunal villi.

In general, the triglycerides of intestinal chylomicrons transported by the CLV are gradually degraded by lipoprotein lipase in the systemic circulation [3]. Such chylomicrons 


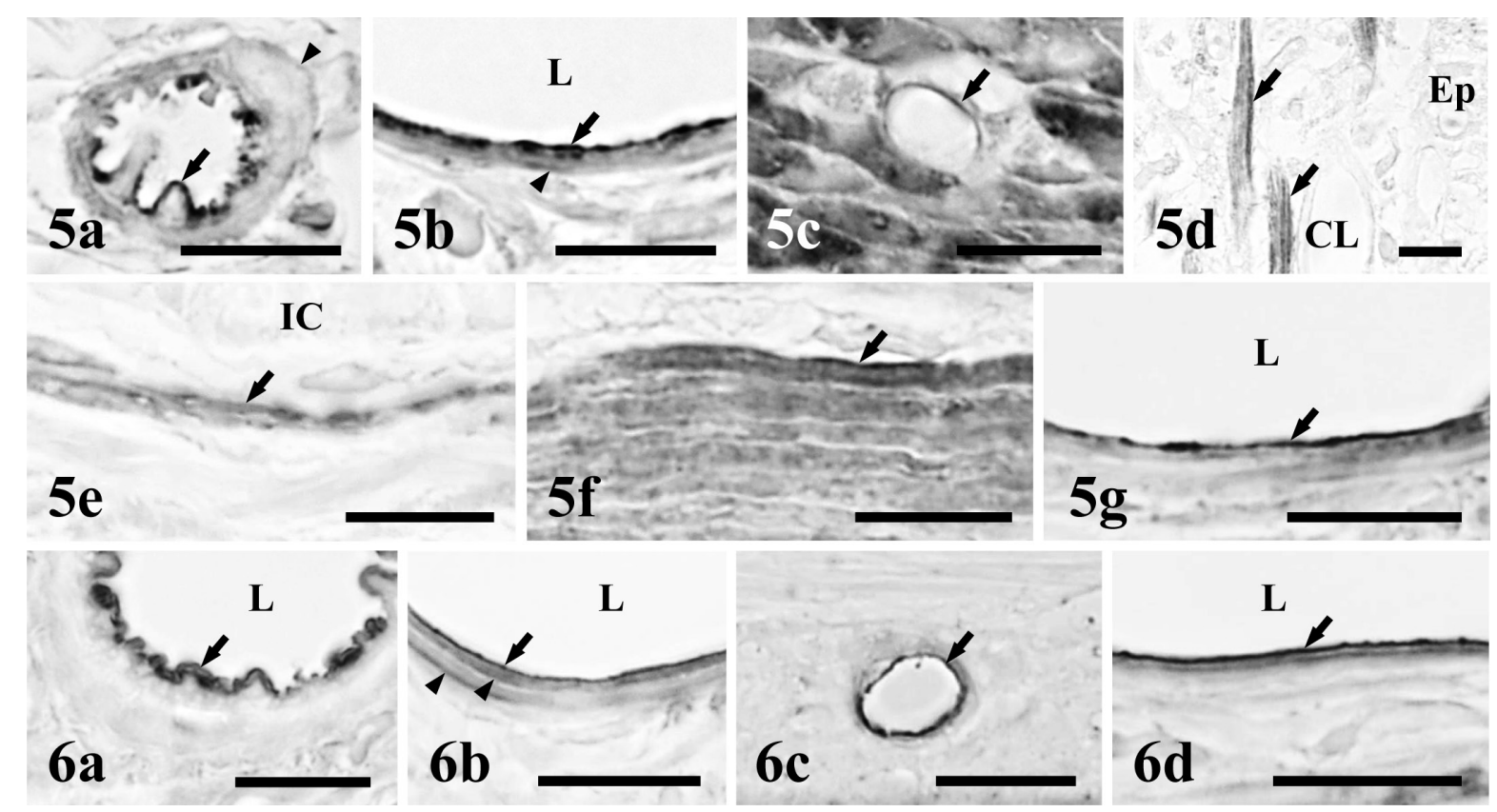

Fig. 5. VLDL receptor-immunopositivities in other intestinal tissue elements. a) A strongly positive endothelium (arrow) and weakly positive smooth muscle cells (arrowhead) of an arteriole in the submucosa. b) A strongly positive endothelium (arrow) and weakly positive smooth muscle cells (arrowhead) of a venule in the submucosa. L, lumen. c) The endothelium (arrow) of a blood capillary in a longitudinal muscle layer. Transverse sections of smooth muscle cells represent various immunopositivities. d) Villous myocytes (arrows) with strongly positive cell membrane and weakly positive cytoplasm in the lamina propria of an intestinal villus. CL, central lymph vessels; Ep, villous epithelium. e) Immunopositive smooth muscle cells (arrow) of the lamina muscularis. IC, intestinal crypt. f) Immunopositive smooth muscle cells in the circular muscle layer (arrow). g) The immunopositive endothelium (arrow) of a lymph vessel in the submucosa. L, lumen. Bar=10 $\mu \mathrm{m}$.

Fig. 6. LDL receptor-immunopositivities in other tissue elements. a) The immunopositive endothelium (arrow) of an arteriole in the submucosa. L, lumen. b) The immunopositive endothelium (arrow) and smooth muscles (arrowheads) of a venule in the submucosa. L, lumen. c) The immunopositive endothelium (arrow) of a blood capillary in the muscular layer. d) The immunopositive endothelium (arrow) of a lymph vessel in the submucosa. L, lumen. Bar=10 $\mu \mathrm{m}$.

become smaller as their triglycerides become more depleted $[6,28]$. The final remnants of chylomicrons are considered to be removed from the systemic circulation in the liver $[3,6$, $8,11]$. The liver also takes up mainly plasma VLDL [9], and hepatocytes are main transporter at least in rats [17]. In the present study, the immunohistochemical detection of VLDL receptor in the endothelium of $\mathrm{sBC}$ supports the notion that minute chylomicrons are transported directly from the small intestine to the liver. Though it has been assumed that the main sources of free fatty acids for the liver are adipocytes, chylomicron remnants and the intestine [35], our results indicate that minute intestinal chylomicrons via the hepatic portal system might be added as an additional main source of hepatic free fatty acids.

Many species of indigenous bacteria reside in the alimentary tract [48]. Gram-negative bacteria are more increased toward the caudal intestine in rats [49]. Gramnegative bacteria possess lipopolysaccharides (LPS) [4], which are recognized and bound by Toll-like receptor-4 (TLR-4) [7]. The secretory form of TLR-4 (sTLR-4) is secreted from the intestinal crypts and other exocrine glands in the rat alimentary tract [25]. The sTLR-4 immunopositive minute vesicles, possibly sTLR-4-LPS complexes, exist in the villous columnar epithelial cells of villous apices in the rat duodenum [24]. In the rat liver, the sTLR-4 immunopositive minute vesicles also exist in the perisinusoidal spaces and hepatocytes [25]. It is well known that LPS are present in the portal vein blood of various human patients, but no LPS are detected in the systemic circulation except in cases of liver disease [20, 39]. The ${ }^{3} \mathrm{H}$-labeled or FITC-labeled LPS injected into rat portal blood are eliminated by Kupffer cells or hepatocytes [2, 27]. Systemic endotoxemia often occurs in dogs, when the amount of LPS infused into the portal veins is greater than the clearance capacity of the liver [5]. However, the pre-i.v. administration of chylomicrons into the vein reduces the mortality of rats with LPS-i.v. infusion [19]. Furthermore, the LPS pre-incubated with chylomicrons or VLDL significantly improve the survival rate in LPS-i.v.administered mice [18]. Therefore, the minute chylomicrons, possibly intestinal VLDL, directly transported to the liver from the intestine probably also play a secondary role in the host defense against LPS derived from the intestine.

ACKNOWLEDGMENT. This work was financially supported in part by a Grant-in-Aid for Scientific Research (no. 23580403) from the Japan Society for the Promotion of 
Science.

\section{REFERENCES}

1. Barthel, L. K. and Raymond, P. A. 1990. Improved method for obtaining 3-microns cryosections for immunocytochemistry. $J$. Histochem. Cytochem. 38: 1383-1388. [Medline] [CrossRef]

2. Bikhazi, A. B., Jurjus, A. R., Kamal, M. T., Al-Housseini, A. M., Saab, R. N., Jaroudi, W. A. and Bitar, K. M. 2001. Kinetics of lipopolysaccharide clearance by Kupffer and parenchyma cells in perfused rat liver. Comp. Biochem. Physiol. C Toxicol. Pharmacol. 129: 339-348.

3. Braun, J. E. A. and Severson, D. L. 1992. Regulation of the synthesis, processing and translocation of lipoprotein lipase. Biochem. J. 287: 337-347. [Medline]

4. Cabeen, M. T. and Jacobs-Wagner, C. 2005. Bacterial cell shape. Nat. Rev. Microbiol. 3: 601-610. [Medline] [CrossRef]

5. Caruana, J. A., Camara, D. S., Schneeberger, G. J. and Nolan, J. P. 1984. The clearance capacity of the canine liver for a portal vein endotoxin infusion. J. Surg. Res. 37: 197-201. [Medline] [CrossRef]

6. Chappell, D. A. and Medh, J. D. 1998. Receptor-mediated mechanisms of lipoprotein remnant catabolism. Prog. Lipid Res. 37: 393-422. [Medline] [CrossRef]

7. Chow, J. C., Young, D. W., Golenbock, D. T., Christ, W. J. and Gusovsky, F. 1999. Toll-like receptor-4 mediates lipopolysaccharide-induced signal transduction. J. Biol. Chem. 274: 10689-10692. [Medline] [CrossRef]

8. Cooper, A. D. 1997. Hepatic uptake of chylomicron remnants. $J$. Lipid Res. 38: 2173-2192. [Medline]

9. Cornetta, K. and Zucker, S. 1983. Organ distribution of circulating very low density lipoproteins (VLDL): fate of hematopoietic growth inhibitory VLDL in the rat. Exp. Hematol. 11: 275-283. [Medline]

10. Dixon, J. B. 2010. Mechanisms of chylomicron uptake into lacteals. Ann. N. Y. Acad. Sci. 1207 Suppl 1: E52-E57. [Medline] [CrossRef]

11. Friedman, H. I. and Nylund, B. 1980. Intestinal fat digestion, absorption, and transport. A review. Am. J. Clin. Nutr. 33: 1108-1139. [Medline]

12. García-Miranda, P., Peral, M. J. and Ilundain, A. A. 2010. Rat small intestine expresses the reelin-Disabled-1 signalling pathway. Exp. Physiol. 95: 498-507. [Medline] [CrossRef]

13. Gianturco, S. H., Lin, A. H. Y., Hwang, S. L. C., Young, J., Brown, S. A., Via, D. P. and Bradley, W. A. 1988. Distinct murine macrophage receptor pathway for human triglyceriderich lipoproteins. J. Clin. Invest. 82: 1633-1643. [Medline] [CrossRef]

14. Gianturco, S. H., Ramprasad, M. P., Lin, A. H. Y., Song, R. and Bradley, W. A. 1994. Cellular binding site and membrane binding proteins for triglyceride-rich lipoproteins in human monocyte-macrophages and THP-1 monocytic cells. J. Lipid Res. 35: 1674-1687. [Medline]

15. Go, G. W. and Mani, A. 2012. Low-density lipoprotein receptor (LDLR) family orchestrates cholesterol homeostasis. Yale J. Biol. Med. 85: 19-28. [Medline]

16. Green, P. H. R. and Glickman, R. M. 1981. Intestinal lipoprotein metabolism. J. Lipid Res. 22: 1153-1173. [Medline]

17. Harkes, L., van Duijne, A. and van Berkel, T. J. C. 1989. Interaction of $\beta$-very-low-density lipoproteins with rat liver cells. Eur. J. Biochem. 180: 241-248. [Medline] [CrossRef]

18. Harris, H. W., Grunfeld, C., Feingold, K. R. and Rapp, J. H. 1990. Human very low density lipoproteins and chylomicrons can protect against endotoxin-induced death in mice. J. Clin. Invest. 86: 696-702. [Medline] [CrossRef]

19. Harris, H. W., Grunfeld, C., Feingold, K. R., Read, T. E., Kane, J. P., Jones, A. L., Eichbaum, E. B., Bland, G. F. and Rapp, J. H. 1993. Chylomicrons alter the fate of endotoxin, decreasing tumor necrosis factor release and preventing death. J. Clin. Invest. 91: 1028-1034. [Medline] [CrossRef]

20. Jacob, A. I., Goldberg, P. K., Bloom, N., Degenshein, G. A. and Kozinn, P. J. 1977. Endotoxin and bacteria in portal blood. Gastroenterology 72: 1268-1270. [Medline]

21. Jonas, A.2002. Lipoprotein structure. pp. 483-504. In: Biochemistry of Lipids, Lipoproteins and Membranes. 4th ed. (Vance, D. E. and Vance, J. E. eds.), Elsevier Science B. V., Amsterdam.

22. Mahley, R. W., Innerarity, T. L., Rall, S. C. Jr. and Weisgraber, K. H. 1984. Plasma lipoproteins: apolipoprotein structure and function. J. Lipid Res. 25: 1277-1294. [Medline]

23. Mansbach, C. M. 2nd. and Gorelick, F. 2007. Development and physiological regulation of intestinal lipid absorption. II. Dietary lipid absorption, complex lipid synthesis, and the intracellular packaging and secretion of chylomicrons. Am. J. Physiol. Gastrointest. Liver Physiol. 293: G645-G650. [Medline] [CrossRef]

24. Mantani, Y., Kamezaki, A., Udayanga, K. G. S., Takahara, E. I., Qi, W. M., Kawano, J., Yokoyama, T., Hoshi, N. and Kitagawa, H. 2011. Site differences of Toll-like receptor expression in the mucous epithelium of rat small intestine. Histol. Histopathol. 26: 1295-1303. [Medline]

25. Mantani, Y., Yokoo, Y., Kamezaki, A., Udayanga, K. G. S., Takahara, E., Takeuchi, T., Kawano, J., Yokoyama, T., Hoshi, N. and Kitagawa, H. 2012. Immunohistochemical detection of toll-like receptor-2, -4 and -9 in exocrine glands associated with rat alimentary tract. J. Vet. Med. Sci. 74: 1429-1438. [Medline] [CrossRef]

26. Méresse, S., Delbart, C., Fruchart, J. C. and Cecchelli, R. 1989. Low-density lipoprotein receptor on endothelium of brain capillaries. J. Neurochem. 53: 340-345. [Medline] [CrossRef]

27. Mimura, Y., Sakisaka, S., Harada, M., Sata, M. and Tanikawa, K. 1995. Role of hepatocytes in direct clearance of lipopolysaccharide in rats. Gastroenterology 109: 1969-1976. [Medline] [CrossRef]

28. Mjøs, O. D., Faergeman, O., Hamilton, R. L. and Havel, R. J. 1975. Characterization of remnants produced during the metabolism of triglyceride-rich lipoproteins of blood plasma and intestinal lymph in the rat. J. Clin. Invest. 56: 603-615. [Medline] [CrossRef]

29. Multhaupt, H. A. B., Gåfvels, M. E., Kariko, K., Jin, H., ArenasElliot, C., Goldman, B. I., Strauss, J. F. 3rd., Angelin, B., Warhol, M. J. and McCrae, K. R. 1996. Expression of very low density lipoprotein receptor in the vascular wall. Analysis of human tissues by in situ hybridization and immunohistochemistry. Am. J. Pathol. 148: 1985-1997. [Medline]

30. Mutoh, M., Komiya, M., Teraoka, N., Ueno, T., Takahashi, M., Kitahashi, T., Sugimura, T. and Wakabayashi, K. 2009. Overexpression of low-density lipoprotein receptor and lipid accumulation in intestinal polyps in Min mice. Int. J. Cancer 125: 2505-2510. [Medline] [CrossRef]

31. Nakamura, Y., Yamamoto, M. and Kumamaru, E. 2000. Very low-density lipoprotein receptor in fetal intestine and gastric adenocarcinoma cells. Arch. Pathol. Lab. Med. 124: 119-122. [Medline]

32. Niemeier, A., Gàfvels, M., Heeren, J., Meyer, N., Angelin, B. and Beisiegel, U. 1996. VLDL receptor mediates the uptake of 
human chylomicron remnants in vitro. J. Lipid Res. 37: 17331742. [Medline]

33. Ockner, R. K., Hughes, F. B. and Isselbacher, K. J. 1969. Very low density lipoproteins in intestinal lymph: origin, composition, and role in lipid transport in the fasting state. J. Clin. Invest. $\mathbf{4 8}$ : 2079-2088. [Medline] [CrossRef]

34. Ockner, R. K. and Jones, A. L. 1970. An electron microscopic and functional study of very low density lipoproteins in intestinal lymph. J. Lipid Res. 11: 284-292. [Medline]

35. Ramasamy, I. 2014. Recent advances in physiological lipoprotein metabolism. Clin. Chem. Lab. Med. 52: 1695-1727. [Medline]

36. Randle, P. J. 1964. The interrelationships of hormones, fatty acid and glucose in the provision of energy. Postgrad. Med. J. 40: 457-463. [Medline] [CrossRef]

37. Risser, T. R., Reaven, G. M. and Reaven, E. P. 1978. Intestinal contribution to secretion of very low density lipoproteins into plasma. Am. J. Physiol. 234: E277-E281. [Medline]

38. Ruan, X. Z., Moorhead, J. F., Tao, J. L., Ma, K. L., Wheeler, D. C., Powis, S. H. and Varghese, Z. 2006. Mechanisms of dysregulation of low-density lipoprotein receptor expression in vascular smooth muscle cells by inflammatory cytokines. Arterioscler. Thromb. Vasc. Biol. 26: 1150-1155. [Medline] [CrossRef]

39. Sanada, Y., Mizuta, K., Urahashi, T., Ihara, Y., Wakiya, T., Okada, N., Yamada, N., Ushijima, K., Otomo, S., Sakamoto, K. and Yasuda, Y. 2011. Impact of hepatic clearance of endotoxin using endotoxin activity assay. Hepatol. Int. 6: 778-782. [Medline] [CrossRef]

40. Schaefer, E. J., Eisenberg, S. and Levy, R. I. 1978. Lipoprotein apoprotein metabolism. J. Lipid Res. 19: 667-687. [Medline]

41. Takahara, E., Mantani, Y., Udayanga, K. G. S., Qi, W. M., Tanida, T., Takeuchi, T., Yokoyama, T., Hoshi, N. and Kitagawa, H. 2013. Ultrastructural demonstration of the absorption and transportation of minute chylomicrons by subepithelial blood capillaries in rat jejunal villi. J. Vet. Med. Sci. 75: 1563-1569. [Medline] [CrossRef]

42. Takahashi, S., Kawarabayasi, Y., Nakai, T., Sakai, J. and Yamamoto, T. 1992. Rabbit very low density lipoprotein receptor: a low density lipoprotein receptor-like protein with distinct ligand specificity. Proc. Natl. Acad. Sci. U.S.A. 89: 9252-9256. [Medline] [CrossRef]

43. Takahashi, S., Suzuki, J., Kohno, M., Oida, K., Tamai, T., Miyabo, S., Yamamoto, T. and Nakai, T. 1995. Enhancement of the binding of triglyceride-rich lipoproteins to the very low density lipoprotein receptor by apolipoprotein $\mathrm{E}$ and lipoprotein lipase. J. Biol. Chem. 270: 15747-15754. [Medline] [CrossRef]

44. Tso, P., Drake, D. S., Black, D. D. and Sabesin, S. M. 1984. Evidence for separate pathways of chylomicron and very lowdensity lipoprotein assembly and transport by rat small intestine. Am. J. Physiol. 247: G599-G610. [Medline]

45. Tso, P., Ragland, J. B. and Sabesin, S. M. 1983. Isolation and characterization of lipoprotein of density less than $1.006 \mathrm{~g} / \mathrm{ml}$ from rat hepatic lymph. J. Lipid Res. 24: 810-820. [Medline]

46. Ueno, M., Wu, B., Nakagawa, T., Nagai, Y., Onodera, M., Huang, C. L., Kusaka, T., Kanenishi, K. and Sakamoto, H. 2010. The expression of LDL receptor in vessels with blood-brain barrier impairment in a stroke-prone hypertensive model. Histochem. Cell Biol. 133: 669-676. [Medline] [CrossRef]

47. Wyne, K. L., Pathak, K., Seabra, M. C. and Hobbs, H. H. 1996. Expression of the VLDL receptor in endothelial cells. Arterioscler. Thromb. Vasc. Biol. 16: 407-415. [Medline] [CrossRef]

48. Yamamoto, K., Qi, W. M., Yokoo, Y., Miyata, H., Udayanga, K. G. S., Kawano, J., Yokoyama, T., Hoshi, N. and Kitagawa, H. 2009. Histoplanimetrical study on the spatial relationship of distribution of indigenous bacteria with mucosal lymphatic follicles in alimentary tract of rat. J. Vet. Med. Sci. 71: 621-630. [Medline] [CrossRef]

49. Yokoo, Y., Miyata, H., Udayanga, K. G. S., Qi, W. M., Takahara, E., Mantani, Y., Yokoyama, T., Kawano, J., Hoshi, N. and Kitagawa, H. 2011. Immunohistochemical and histoplanimetrical study on the spatial relationship between the settlement of indigenous bacteria and the secretion of bactericidal peptides in rat alimentary tract. J. Vet. Med. Sci. 73: 1043-1050. [Medline] [CrossRef] 